\title{
APPLICATION OF SOMATIC EMBRYOGENESIS AND BIOREACTOR TECHNIQUES IN MICROPROPAGATION OF TROPICAL LILY CONCA D'OR (ORIENT X TRUMPET)
}

\author{
Nguyen Thanh Quang, ${ }^{1}$ Tran Van Minh²
}

\begin{abstract}
The lily is considered one of the highest value cutting flowers as well as is popular to the majority. Bulbs are often imported from the Netherland with an expensive price. Thus, it is difficult to sell commercial lily flowers in the domestic market and international trade. This study focused on mass producing the source of somatic embryos with a high regeneration ability used for the lily micropropagation. Internodes were cultured on MS medium and supplemented with $0.1 \mathrm{mg} / \mathrm{l} \mathrm{BA}$ and $0.5 \mathrm{mg} / \mathrm{l} \mathrm{NAA}$ to induce callus, while embryogenic cells reached the highest value at $98.2 \%$ before such embryogenic callus was then multiplied on the same media within 5 weeks. The suitable media for somatic embryos regeneration was MS medium supplemented with $0.5 \mathrm{mg} / \mathrm{l} \mathrm{BA}$ and $0.25 \mathrm{mg} / \mathrm{l}$ NAA which after 5 weeks of culture gave us a shoot number of 3.7 shoots/clusters, a shoot height of $87.3 \mathrm{~mm}$, a leaf diameter of $7.7 \mathrm{~mm}$. Multiple shoots regenerated from embryogenic cells were then used as materials for micropropagation. Results showed that the highest data for multiple shoot multiplication was reached in the bioreactor culture system with the maximum number of shoot height $(100.25 \mathrm{~mm})$, shoot number $(7.1$ shoot/cluster) and fresh weight of shoots $(1470.94 \mathrm{mg} /$ cluster). The suitable medium for rooting was MS medium supplemented with $0.5 \mathrm{mg} / \mathrm{l} \mathrm{NAA}$.
\end{abstract}

UDC Classification: 57.01; DOI: http://dx.doi.org/10.12955/cbup.v5.1104

Keywords: Conca D'or, bulb, somatic embryo, induction, proliferation, regeneration

\section{Introduction}

The lily flower belongs to the Liliaceae family which consists of around 200 genus and 3000 species, originates from South - West Asia and North America and were imported to Vietnam in the French colonial period (Blaney and Roberts, 1966; McRae, 1988; Lian et al, 2003; Woodcock and Stearn, 1950; Zhang et al, 2014). In Vietnam, the lily is now considered as one of the highest value cutting flower as well as being popular to the majority of people thanks to its pure beauty, passionate perfumes and long shelf life.

Lily cultivation more often than not has strong economic potential and brings with it higher profit than other flowers. However, lily cultivation in Vietnam has had many difficulties especially the lack of a source of bulb with high quality and which still hasn't had a lily propagation system. Thus, almost all bulbs that are used today must be imported from the Netherland with an expensive price. Therefore, it is very difficult to sell commercial lily flower in the domestic and international market.

Lilies can be propagated by some traditional methods, in particular, natural divisions, stem bulblets, bulbs and scaling (Zhang et al., 2014). However, with such ways exist some disadvantages such as: a low amplification coefficient, slow growth rate, the appearance of variability in the next generations, etc...

There are many organs that can be used as starting material in lily micropropagation such as: the bulb scale, shoot tip, petal and receptacle (Bong et al., 2004; Hoshi et al., 2004, Lan et al., 2009; Pelkonen, 2005; Suzuki et al., 2002). Stem (Suzuki et al., 2002; Zhang et al., 2014), thin cell layer culture (Nhut et al., 2002) and bioreactor techniques (Lian et al., 2003) are used in somatic embryogenesis. The high concentration of auxin is really necessary to induce callus and the embryo in the starting stage (Komamine et al., 2005; Pierik, 1987). Almost all studies use 2,4-D and picloram to induce callus and embryo in the starting stage and improve the regenerative ability through using plant growth regulators belonged to the cytokinin group such as: BAP, TDZ and kin etin (Nhut et al., 2002).

Building up a lily micropropagation system by using a somatic embryo culture technique and using regenerated shoots from an embryo in the in vitro propagation is examined as the permanent solution to mass produce starting materials serving for the lily bulb production with high quality.

\section{Materials and Methods}

The bulbs of Lilium oriental hybrid 'Conca Dor' (Orient x Trumpet) were purchased from the De Jong Lelies Holland and bloomed in HCMC and Sa Dec (Dong Thap province, Mekong River Delta). Such

\footnotetext{
${ }^{1}$ International University, Vietnam National University Ho Chi Minh City, Viet Nam, nguyenthanhquang1411@gmail.com

${ }^{2}$ International University, Vietnam National University Ho Chi Minh City, Viet Nam, drminh.ptntd@ yahoo.com
} 
bulbs were put into a tray and covered by a layer of coconut fiber at $28^{0} \mathrm{C}$, developed stems of approximately $7 \mathrm{~cm}$ long within two weeks.

Explant sterilization: 6 external leaves of each stem approximately $4-5 \mathrm{~cm}$ in length were removed. Next, the stems were submerged in detergent solution and this followed by rinsing continuously with running tap water. Under sterile conditions in a flow-cabinet, the surface of stems was sterilized in $70 \%$ ethanol in 30 seconds and then washed 3 times with sterile distilled water before they were disinfected continuously for 6 minutes in $0.1 \% \mathrm{HgCl}_{2}$ solution, to which two drops of Tween 20 (Fulka, Germany) had been added and then washed 5 times with sterile distilled water.

Cultural materials: young leaves (10-12 young leaves per stem) and nodes (5-6 nodes per stem) were excised from stems and used as cultural materials in the experiments.

Cultural medium: MS basal medium (Murashige and Skoog, 1962) supplemented with $10 \%$ coconut water, $0.1 \% \mathrm{AC}, 0.8 \%$ agar, $3 \%$ sucrose and plant growth regulators such as: BA and NAA in different concentrations. The medium was adjusted to $\mathrm{pH} 5.8$ before being autoclaved at $121^{\circ} \mathrm{C}, 1 \mathrm{~atm}$ for 20 minutes.

All cultures were incubated at $24 \pm 2^{\circ} \mathrm{C}$ with a photoperiod of $16 \mathrm{~h}$ per day at a light intensity of 11.1 $\mu \mathrm{mol} \mathrm{m} \mathrm{m}^{-2}$ fluorescent light and $60 \pm 5 \%$ relative humidity.

Data was analyzed by using one way ANOVA. Each experiment had 3 replicates, each replicate had 4 bottles and each bottle had 5 explants. All analysis of the results was carried out by using MSTATC software version 2.0 of the Michigan University, USA. The level of significance in the experiments was set at 0.05 and will be classified into the LSD test.

\section{Experiment Design}

Experiment 1: The effect of explants on the embryogenic callus induction: MS basal medium supplemented with $0.1 \mathrm{mg} / \mathrm{l} \mathrm{BA}$ and $0.5 \mathrm{mg} / \mathrm{l} \mathrm{NAA}$. Culture material: Areca leaf and internode. Data collection: callus induction rate, somatic embryo induction rate, callus and somatic embryo induction rate. Data was recorded 4 weeks after culture.

Experiment 2: The effect of NAA on the multiplication of embryogenic callus: Culture medium: MS basal medium supplemented with $0.1 \mathrm{mg} / \mathrm{l} \mathrm{BA}$ and NAA $(0,0.1,0.25,0.5,0.75 \mathrm{mg} / \mathrm{l})$. Culture material: Friable and compact embryogenic callus (1 g embryogenic callus per cluster). Data collection: fresh weight of embryogenic callus per cluster (mgFW/cluster), proliferation rate of embryogenic callus and number of shoot (shoots/cluster). Data was recorded 5 weeks after culture

Experiment 3: The effect of BA and NAA on somatic embryos regeneration: Culture medium: MS basal medium supplemented with the combination of NAA $(0,0.1,0.25 \mathrm{mg} / \mathrm{l})$ and various concentrations of BA $(0,0.1,0.25,0.5,0.75 \mathrm{mg} / \mathrm{l})$. Culture material: Friable and compact embryogenic callus ( $1 \mathrm{~g}$ embryogenic callus per cluster). Data collection: number of shoot per cluster, height of shoot $(\mathrm{mm})$ and leaf diameter $(\mathrm{mm})$. Data was recorded 5 weeks after culture.

Experiment 4: The effect of NAA, IAA, IBA on shoot multiplication: Culture medium: MS basal medium supplemented with the combination of $0.5 \mathrm{mg} / \mathrm{l} \mathrm{BA}$ and different concentrations of NAA (0, $0.1,0.2,0.3 \mathrm{mg} / \mathrm{l})$, IAA $(0,0.1,0.2,0.3 \mathrm{mg} / \mathrm{l})$ and IBA $(0,0.1,0.2,0.3 \mathrm{mg} / \mathrm{l})$. Culture material: in vitro shoots. Data collection: number of shoot per cluster, number of leaf per cluster, height of shoot (mm) and leaf diameter $(\mathrm{mm})$. Data was recorded 5 weeks after culture.

Experiment 5: The effect of the temporary immersion bioreactor system on shoot multiplication. Culture medium: MS basal medium supplemented with $0.5 \mathrm{mg} / \mathrm{l} \mathrm{BA}, 0.2 \mathrm{mg} / \mathrm{l} \mathrm{NAA}$ and various immersion frequencies ( 1 minute each 4 hours, 2 minutes each 4 hours, 3 minutes each 4 hours and 4 minutes each 4 hours). Cultural materials: in vitro shoots. Data collection: number of shoot per cluster, height of shoot $(\mathrm{mm})$, fresh weight of shoot per cluster $(\mathrm{mg})$ and proliferation rate of shoot. Data was recorded 5 weeks after culture.

Experiment 6: The effect of NAA on the rooting: Culture medium: MS basal medium supplemented with $10 \%$ coconut water, $0.8 \%$ agar, $0.1 \% \mathrm{AC}, 3 \%$ sucrose and difference concentrations of NAA ( 0 , $0.1,0.3,0.5 \mathrm{mg} / \mathrm{l})$. Culture material: in vitro shoots. Data collection: rooting rate, number of roots and length of root $(\mathrm{mm})$. Data was recorded 4 weeks after culture. 


\section{Results and Discussion}

\section{Effect of Explants on Embryogenic Callus Induction}

Effects of explants on the induction of embryogenic callus were described in Table 1 after 4 weeks of the culture. According to the result, internode was the most suitable starting material in the embryogenic callus induction with the maximum number of callus induction rate (18.7\%), somatic embryo induction rate $(79.5 \%)$ and callus and somatic embryo induction rate $(98.2 \%)$ after 4 weeks of the culture (Table 1). The results were far higher than those using areca leaf as a starting material which only reached $14.7 \%$ in callus induction rate, $16.0 \%$ in embryo induction rate and $22.7 \%$ in callus and somatic embryo induction rate after 4 weeks of the culture.

Table 1: The effect of explants on embryogenic callus induction

\begin{tabular}{|l|l|l|l|}
\hline Starting material & $\begin{array}{l}\text { Callus induction } \\
\text { rate }(\boldsymbol{\%})\end{array}$ & $\begin{array}{l}\text { Somatic embryo } \\
\text { induction rate } \mathbf{( \% )}\end{array}$ & $\begin{array}{l}\text { Callus and somatic embryo } \\
\text { induction rate (\%) }\end{array}$ \\
\hline Areca Leaf & 14.7 & 16.0 & 22.7 \\
\hline Internode & 18.7 & 79.5 & 98.2 \\
\hline $\mathbf{M}$ & 16.7 & 47.7 & 60.4 \\
\hline $\mathbf{C V}(\boldsymbol{\%})$ & 18.3 & 12.7 & 11.9 \\
\hline
\end{tabular}

Source: Author

\section{Effect of NAA on Multiplication of Embryogenic Callus}

The effects of NAA on the embryogenic callus multiplication were described in Table 2 after 5 weeks of culture. The results showed that on hormone - free basal MS fresh weight of embryogenic callus per cluster, proliferation rate of embryogenic callus fresh weight and number of shoot per cluster only reached at the low rate, standing at $1089.7 \mathrm{mg} \mathrm{FW/cluster,} 1.1$ fold and 1.3 shoots/cluster respectively. However, the highest value was observed at the treatment using culture medium supplemented with $0.1 \mathrm{mg} / \mathrm{l} \mathrm{BA}$ and $0.5 \mathrm{mg} / \mathrm{l} \mathrm{NAA}$ with the maximum number of fresh weight of embryogenic callus per cluster (2719.7 mg FW/cluster), proliferation rate of embryogenic callus fresh weight (2.6 folds) and number of shoot per cluster ( 2.7 shoots/cluster). According to the analysis above, it can be concluded that NAA plays an instrumental role on the embryogenic callus multiplication (Table 2).

\begin{tabular}{|l|l|l|l|}
\hline \multicolumn{2}{|l|}{ Table 2: The effect of NAA on multiplication of embryogenic callus } \\
\hline $\begin{array}{l}\text { NAA } \\
(\mathbf{m g} / \mathbf{l})\end{array}$ & $\begin{array}{l}\text { Fresh weight of embryogenic callus } \\
\text { per cluster (mgFW/cluster) }\end{array}$ & $\begin{array}{l}\text { Proliferation rate of } \\
\text { embryogenic callus }\end{array}$ & $\begin{array}{l}\text { Number of shoot } \\
\text { (shoots/cluster) }\end{array}$ \\
\hline $\mathbf{0 . 0 0}$ & $1089.7^{\mathrm{c}}$ & $1.1^{\mathrm{c}}$ & $1,3^{\mathrm{c}}$ \\
\hline $\mathbf{0 . 1 0}$ & $1522.0^{\mathrm{b}}$ & $1.5^{\mathrm{b}}$ & $1.3^{\mathrm{c}}$ \\
\hline $\mathbf{0 . 2 5}$ & $1573.0^{\mathrm{b}}$ & $1.6^{\mathrm{b}}$ & $2.0^{\mathrm{b}}$ \\
\hline $\mathbf{0 . 5 0}$ & $2719.7^{\mathrm{a}}$ & $2.6^{\mathrm{a}}$ & $2.7^{\mathrm{a}}$ \\
\hline $\mathbf{0 . 7 5}$ & $2566.3^{\mathrm{a}}$ & $2.6^{\mathrm{a}}$ & $2.3^{\mathrm{a}}$ \\
\hline $\mathbf{M}$ & 1865.7 & 1.9 & 119.0 \\
\hline $\mathbf{C V}(\boldsymbol{\%})$ & 3.5 & 5.4 & 35.3 \\
\hline $\mathbf{L S D}(\mathbf{0 . 0 5})$ & 119.0 & 0.1 & 1.9 \\
\hline Source: Author & \multicolumn{2}{l}{} \\
\hline
\end{tabular}

\section{Effect of BA and NAA on Somatic Embryos Regeneration}

The effects of BA and NAA on the embryogenic callus regeneration were described in Table 3 after 5 weeks of culture. The results showed that on hormone - free basal MS number of shoot per cluster, height of shoot $(\mathrm{mm})$ and leaf diameter $(\mathrm{mm})$ only reached at the low rate, standing at 1.0 shoot/cluster, $35.3 \mathrm{~mm}$ and $1.7 \mathrm{~mm}$ respectively. However, the highest value was observed at the treatment using culture medium supplemented with $0.5 \mathrm{mg} / \mathrm{l} \mathrm{BA}$ and $0.25 \mathrm{mg} / \mathrm{l} \mathrm{NAA}$ with the maximum number of shoot number $(3.7$ shoots/cluster), height of shoot $(87.3 \mathrm{~mm}$ ) and leaf diameter $(7.7 \mathrm{~mm})$. According to the analysis above, it can be concluded that the appropriate medium for the somatic embryos regeneration under in vitro condition is MS basal medium with the combined concentration of $0.5 \mathrm{mg} / \mathrm{l} \mathrm{BA}$ and $0.25 \mathrm{mg} / \mathrm{l} \mathrm{NAA}$ (Table 3 ). 
Table 3: The effect of BA and NAA on somatic embryos regeneration

\begin{tabular}{|l|l|l|l|l|}
\hline $\begin{array}{l}\text { BA } \\
(\mathbf{m g} / \mathbf{l})\end{array}$ & $\begin{array}{l}\text { NAA } \\
(\mathbf{m g} / \mathbf{l})\end{array}$ & $\begin{array}{l}\text { Number of shoot per } \\
\text { cluster }\end{array}$ & $\begin{array}{l}\text { Height of shoot } \\
(\mathbf{m m})\end{array}$ & $\begin{array}{l}\text { Leaf diameter } \\
(\mathbf{m m})\end{array}$ \\
\hline $\mathbf{0 . 0 0}$ & $\mathbf{0 . 0 0}$ & $1.0^{\mathrm{c}}$ & $35.3^{\mathrm{f}}$ & $1.7^{\mathrm{e}}$ \\
\hline $\mathbf{0 . 1 0}$ & $\mathbf{0 . 1 0}$ & $1.3^{\mathrm{bc}}$ & $36.7^{\mathrm{f}}$ & $2.7^{\mathrm{de}}$ \\
\hline $\mathbf{0 . 1 0}$ & $\mathbf{0 . 2 5}$ & $1.7^{\mathrm{bc}}$ & $44.7^{\mathrm{ef}}$ & $3.0^{\mathrm{cde}}$ \\
\hline $\mathbf{0 . 2 5}$ & $\mathbf{0 . 1 0}$ & $2.3^{\mathrm{ac}}$ & $51.3^{\mathrm{de}}$ & $3.7^{\mathrm{cd}}$ \\
\hline $\mathbf{0 . 2 5}$ & $\mathbf{0 . 2 5}$ & $2.7^{\mathrm{a}}$ & $61.7^{\mathrm{d}}$ & $4.3^{\mathrm{c}}$ \\
\hline $\mathbf{0 . 5 0}$ & $\mathbf{0 . 1 0}$ & $3.3^{\mathrm{a}}$ & $74.7^{\mathrm{c}}$ & $7.3^{\mathrm{ab}}$ \\
\hline $\mathbf{0 . 5 0}$ & $\mathbf{0 . 2 5}$ & $3.7^{\mathrm{a}}$ & $87.3^{\mathrm{b}}$ & $7.7^{\mathrm{a}}$ \\
\hline $\mathbf{0 . 7 5}$ & $\mathbf{0 . 1 0}$ & $2.7^{\mathrm{ab}}$ & $90.7^{\mathrm{b}}$ & $6.0^{\mathrm{b}}$ \\
\hline $\mathbf{0 . 7 5}$ & $\mathbf{0 . 2 5}$ & $3.3^{\mathrm{a}}$ & $107.3^{\mathrm{a}}$ & $6.7^{\mathrm{ab}}$ \\
\hline $\mathbf{M}$ & & 2.4 & 65.5 & 4.8 \\
\hline $\mathbf{C V}(\boldsymbol{\%})$ & & 35.2 & 10.0 & 18.9 \\
\hline LSD(0.05) & 1.5 & 11.2 & 1.5 \\
\hline
\end{tabular}

Source: Author

\section{Effect of NAA, IAA, IBA on Shoot Multiplication}

The effects of the NAA/IAA/IBA on the shoot multiplication were described in Table 4 after 5 weeks of culture. The results showed that on hormone - free basal MS number of shoot per cluster, height of shoot $(\mathrm{mm})$, number of leaf per cluster and leaf diameter $(\mathrm{mm})$ only reached at the low rate, standing at 1.3 shoot/cluster, $60.3 \mathrm{~mm}, 3.3$ leaves per cluster and $4.7 \mathrm{~mm}$, respectively.

Data collections reached the highest value, accounting for 6.7 shoots per cluster, $96.7 \mathrm{~mm}$ in height of shoot, 7.7 leaves per cluster and $11.3 \mathrm{~mm}$ in leaf diameter when using culture medium supplemented with $0.5 \mathrm{mg} / \mathrm{l} \mathrm{BA}$ and $0.2 \mathrm{mg} / \mathrm{l} \mathrm{NAA}$.

The combination of $0.5 \mathrm{mg} / \mathrm{l} \mathrm{BA}$ and $0.2 \mathrm{mg} / \mathrm{l}$ IAA demonstrated 5.0 shoot/cluster, $92.7 \mathrm{~mm}$ height of shoot, 5.7 leaf/cluster and $10.7 \mathrm{~mm}$ leaf diameter.

Additionally, the combination of $0.5 \mathrm{mg} / \mathrm{l} \mathrm{BA}$ and $0.2 \mathrm{mg} / \mathrm{l} \mathrm{IBA}$ also reached 4.7 shoots per cluster, $91.0 \mathrm{~mm}$ in height of shoot, 6.0 leaves per cluster and $9.7 \mathrm{~mm}$ in leaf diameter.

Therefore, the appropriate medium for the shoot multiplication under in vitro conditions is MS basal medium with the combined concentration of $0.5 \mathrm{mg} / \mathrm{l} \mathrm{BA}$ and $0.2 \mathrm{mg} / \mathrm{l} \mathrm{NAA}$ after 5 weeks of culture (Table 4)

\begin{tabular}{|l|l|l|l|l|}
\hline Table 4: The effect of NAA/IAA/IBA on shoot multiplication \\
\hline Treatment & $\begin{array}{l}\text { Number of shoot } \\
\text { per cluster }\end{array}$ & $\begin{array}{l}\text { Height of shoot } \\
(\mathbf{m m})\end{array}$ & $\begin{array}{l}\text { Number of leaf per } \\
\text { cluster }\end{array}$ & $\begin{array}{l}\text { Leaf diameter } \\
\text { (mm) }\end{array}$ \\
\hline Control & $1.3^{\mathrm{d}}$ & $60.3^{\mathrm{e}}$ & $3.3^{\mathrm{f}}$ & $4.7^{\mathrm{g}}$ \\
\hline NAA(0.1) & $5.3^{\mathrm{b}}$ & $85.7^{\mathrm{c}}$ & $6.7^{\mathrm{b}}$ & $8.3^{\mathrm{de}}$ \\
\hline NAA(0.2) & $6.7^{\mathrm{a}}$ & $96.7^{\mathrm{a}}$ & $7.7^{\mathrm{a}}$ & $11.3^{\mathrm{a}}$ \\
\hline NAA(0.3) & $4.7^{\mathrm{b}}$ & $91.0^{\mathrm{b}}$ & $5.7^{\mathrm{cd}}$ & $7.3^{\mathrm{e}}$ \\
\hline IAA(0.1) & $3.3^{\mathrm{c}}$ & $86.3^{\mathrm{c}}$ & $5.0^{\mathrm{de}}$ & $8.3^{\mathrm{de}}$ \\
\hline IAA(0.2) & $5.0^{\mathrm{b}}$ & $92.7^{\mathrm{b}}$ & $5.7^{\mathrm{cd}}$ & $10.7^{\mathrm{ab}}$ \\
\hline IAA(0.3) & $3.0^{\mathrm{c}}$ & $79.0^{\mathrm{d}}$ & $4.3^{\mathrm{e}}$ & $6.0^{\mathrm{f}}$ \\
\hline IBA(0.1) & $3.0^{\mathrm{c}}$ & $84.3^{\mathrm{c}}$ & $4.7^{\mathrm{e}}$ & $8.7^{\mathrm{cd}}$ \\
\hline IBA(0.2) & $4.7^{\mathrm{b}}$ & $91.0^{\mathrm{b}}$ & $6.0^{\mathrm{bc}}$ & $9.7^{\mathrm{bc}}$ \\
\hline IBA(0.3) & $3.0^{\mathrm{c}}$ & $78.7^{\mathrm{f}}$ & $4.7^{\mathrm{e}}$ & $5.3^{\mathrm{fg}}$ \\
\hline M & 4.0 & 84.6 & 5.4 & 8.0 \\
\hline CV\% & 17.9 & 2.3 & 9.6 & 8.8 \\
\hline LSD $(\mathbf{0 . 0 5})$ & 1.2 & 3.3 & 0.9 & 1.2 \\
\hline Source: Author & & & & \\
\hline
\end{tabular}

\section{Effect of the Temporary Immersion Bioreactor System on Shoot Multiplication}

The effects of the temporary immersion bioreactor system on the shoot multiplication were described in Table 5 after 5 weeks of culture. The results showed that using the temporary immersion bioreactor with the immersion frequencies (1 minute each 4 hours, 2 minutes each 4 hours, 3 minutes each 4 
hours and 4 minutes each 4 hours) on the liquid culture medium had positive effects on the shoot multiplication and reached the highest value at treatment using immersion frequency ( 3 minutes each 4 hours) with a maximum for the height of shoots $(100.25 \mathrm{~mm})$, number of shoot per cluster (7.1 shoots per cluster), fresh weight of shoot per cluster (1470.94 mg/cluster) and proliferation rate of shoot (3.55 fold), compared with culturing on the semi-solid MS. Thus, immersion frequency (3 minutes each 4 hours) is the most effective treatment for shoot multiplication.

\begin{tabular}{|l|l|l|l|l|}
\hline Table 5: The effect of the temporary immersion bioreactor system on shoot multiplication \\
\hline \begin{tabular}{|l|l|l|l|} 
Immersion frequency \\
(mins/each 4 hours)
\end{tabular} & $\begin{array}{l}\text { Height of shoot } \\
(\mathbf{m m})\end{array}$ & $\begin{array}{l}\text { Number of } \\
\text { (shoot/cluster) }\end{array}$ & $\begin{array}{l}\text { Fresh weight of } \\
\text { shoot }(\mathbf{m g} / \text { cluster) }\end{array}$ & $\begin{array}{l}\text { Proliferation } \\
\text { rate of shoot }\end{array}$ \\
\hline Agar & $92,52^{\mathrm{b}}$ & $6,11^{\mathrm{b}}$ & $1293,52^{\mathrm{b}}$ & $3.06^{\mathrm{c}}$ \\
\hline $\mathbf{1}$ & $86.95^{\mathrm{b}}$ & $7.40^{\mathrm{a}}$ & $913.24^{\mathrm{c}}$ & $3.70^{\mathrm{a}}$ \\
\hline $\mathbf{2}$ & $91.02^{\mathrm{b}}$ & $6.95^{\mathrm{a}}$ & $1306.76^{\mathrm{b}}$ & $3.47^{\mathrm{b}}$ \\
\hline $\mathbf{3}$ & $100.25^{\mathrm{a}}$ & $7.10^{\mathrm{a}}$ & $1470.94^{\mathrm{a}}$ & $3.55^{\mathrm{ab}}$ \\
\hline $\mathbf{4}$ & $93.60^{\mathrm{ba}}$ & $6.34^{\mathrm{b}}$ & $1269.24^{\mathrm{b}}$ & $3.17^{\mathrm{c}}$ \\
\hline $\mathbf{M}$ & 93.53 & 6.78 & 1250.73 & 3.4 \\
\hline CV\% & 5.39 & 3.31 & 4.61 & 3.2 \\
\hline LSD 0.05 & 9.18 & 0.58 & 149.21 & 0.2 \\
\hline
\end{tabular}

Source: Author

\section{Effect of NAA on Rooting}

The effects of NAA on the rooting were described in Table 6 after 4 weeks of culture. The results showed that on hormone - free basal MS rooting rate, number of roots and length of root $(\mathrm{mm})$ only reached at the low rate, standing at $3.3 \%, 0.3$ root per shoot and $5.0 \mathrm{~mm}$ respectively. However, a higher concentration of NAA has greater data values and the highest value was observed at the treatment using culture medium supplemented with $0.5 \mathrm{mg} / \mathrm{l}$ NAA with the maximum number of rooting rate $(78.3 \%)$, number of roots (3.7 roots per shoot) and length of root $(23.3 \mathrm{~mm})$.

\begin{tabular}{|l|l|l|l|}
\hline Table 6: The effect of NAA on the rooting after 4 weeks of culture \\
\hline NAA concentration (mg/l) & Rooting rate (\%) & Number of roots & $\begin{array}{l}\text { Length of root } \\
(\mathbf{m m})\end{array}$ \\
\hline $\mathbf{0 . 0}$ & $3.3^{\mathrm{c}}$ & $0.3^{\mathrm{c}}$ & $5.0^{\mathrm{b}}$ \\
\hline $\mathbf{0 . 1}$ & $63.3^{\mathrm{b}}$ & $2.3^{\mathrm{b}}$ & $19.3^{\mathrm{a}}$ \\
\hline $\mathbf{0 . 3}$ & $71.7^{\mathrm{a}}$ & $3.3^{\mathrm{ab}}$ & $21.3^{\mathrm{a}}$ \\
\hline $\mathbf{0 . 5}$ & $78.3^{\mathrm{a}}$ & $3.7^{\mathrm{a}}$ & $23.3^{\mathrm{a}}$ \\
\hline $\mathbf{M}$ & 54.1 & 2.4 & 17.2 \\
\hline $\mathbf{C V \%}$ & 7.0 & 23.9 & 27.5 \\
\hline LSD $(\mathbf{0 . 0 5})$ & 7.2 & 1.1 & 8.9 \\
\hline Source: Author & \multicolumn{2}{|}{} \\
\hline
\end{tabular}

\section{Conclusion}

The suitable starting material for the induction of embryogenic callus was internodes culturing on the MS basal medium with the combined concentration of $0.1 \mathrm{mg} / \mathrm{l} \mathrm{BA}$ and $0.5 \mathrm{mg} / \mathrm{l} \mathrm{NAA}$ with the maximum number of callus and somatic embryo induction rate (98.2\%) after 4 weeks of culture. The appropriate medium for the multiplication of embryogenic cells was MS supplemented with $0.1 \mathrm{mg} / \mathrm{l}$ BA and $0.5 \mathrm{mg} / \mathrm{l}$ NAA giving a fresh weight of embryogenic cell $2719.7 \mathrm{mg} / \mathrm{cluster}$, proliferation rate 2.6 fold and number of shoot per cluster 2.7 shoots/cluster after 5 weeks of culture. The suitable media for regeneration of embryogenic cells was MS supplemented with $0.5 \mathrm{mg} / \mathrm{l} \mathrm{BA}$ and $0.25 \mathrm{mg} / \mathrm{l} \mathrm{NAA}$ giving 3.7 shoots/cluster, shoot height $87.3 \mathrm{~mm}$, leaf diameter $7.7 \mathrm{~mm}$ after 5 weeks of culture.

Multiple shoots regenerated from embryogenic cells were used as materials for micropropgation. Results showed that the highest data for multiple shoot multiplication was on semi-solid MS supplemented with $0.2 \mathrm{mg} / \mathrm{l} \mathrm{NAA}$ and $0.5 \mathrm{mg} / \mathrm{l} \mathrm{BA}$ giving a proliferation rate of 6.7 shoots/cluster, shoot height $96.7 \mathrm{~mm}$ and leaf number 7.7. In the bioreactor culture, results reached the highest value with the maximum number of shoot height $(100.25 \mathrm{~mm})$, shoot number $(7.1$ shoot /cluster) and fresh weight of shoots (1470.94 mg/cluster). The suitable media for rooting was MS medium supplemented 
with $0.5 \mathrm{mg} / \mathrm{l}$ NAA with the maximum rooting rate $(78.3 \%)$, number of roots (3.7 roots per shoot) and length of root $(23.3 \mathrm{~mm})$.

\section{References}

Blaney, L. T. \& and Roberts, A. N. (1966). Growth and development of the Easter lily bulb, Lilium longiflorum Thunb. Scientia Horticulturae, 89, 643-650.

Bong, H. H. A., Hee, J. Y. A., Byeoung, W. Y. A., \& Kee, Y. P. B. (2004). In vitro propagation of Lilium longiflorum 'Georgia' by shoot formation as influenced by addition of liquid medium. Scientia Horticulturae, 103, 39-49.

Hoshi, Y., Kondo, M., Mori, S., Adachi, Y., Nakano, M., \& Kobayashi, H. (2004). Production of transgenic lily plants by Agrobacterium - mediated transformation. Plant Cell Report,22, 359- 364.

Komamine, A., Murata, N. \& Nomura, K. (2005). Mechanism of somatic embryogenesis in carrot suspension culturesMorphology, physiology, biochemistry and molecular biology. In Vitro Cellelluar \& Developmental Biology-Plant,41, 6- 10.

Lan, H. T., Hong, P. I., Huang, C. C., Chang, W. C. \& Lin, C. S. (2009). High-frequency direct somatic embryogenesis from leaf tissues of Drimiopsis kirkii Baker (giant squill). In Vitro Cellelluar \& Developmental Biology-Plant,45, 44-47.

Lian, M. L., Debasis, C. \& Kee, Y. P. (2003). Growth of Lilium oriental Hybrid 'Casablanca' bulblet using bioreactor culture. Scientia Horticulturae, 97(1), 41-48.

McRae, E. A. (1998). Lilies: A guide for growers and collectors. Timber Press, Oregon, USA, 392.

Murashige, T. \& Skoog, F. (1962). A revised medium for rapid growth and bioassay with tobacco tissue cultures. Physiologia Plantarum, 15: 473-497.

Nhut, D. T., Le, B. V., Minh, N. T., Teixeira de Silva, J., Fukai, S., Tanaka, M., \& Tran Thanh Van, K. (2002). Somatic embryogenesis through pseudo-bulblet transverse thin cell layer of Lilium longiflorum. Plant Growth Regulation, 37, 193198.

Pelkonen, V. P. (2005). Biotechnological approaches in lily (Lilium) production. Oulu: Oulu University press.

Pierik, R. L. M. (1987) In vitro culture of higher plants. Martinus Nijhoff Publishers, Dordrecht, Netherlands.

Suzuki, S., Oota, M., \& Nakano. M. (2002). Embryogenic callus induction from leaf explants. Scientia Horticulturae, 95, 123-132.

Woodcock, H. B. D. \& Stearn, W. T. (1950). Lilies of the World. Country Life Ltd, London, England, 431.

Zhang, Y., Li, A. M., Zhang, Z. H., Chen, X. D., \& Zhao, W. W. (2014). Study on tissue culture to high quality ornamental lily of Conca D'or. Northern Horticulture, 2014-18. 